Karadeniz Uluslararası Bilimsel Dergi

Volume: 47, Autumn-2020, p. (29-43)

ISSN: 1308-6200 DOI Number: https://doi.org/10.17498/kdeniz.764046

Research Article

Received: July 4, 2020 | Accepted: July 25, 2020

This article was checked by intihal.net.

\title{
KÜLTÜREL BELLEK MEKÂNI VE MİLLİ KİMLİK YARATMADA PINARBAŞI AĞITLARININ IŞ̧LEVI*
}

\section{CULTURAL MEMORY SPACE AND FUNCTION OF PINARBAŞI LAMENTATION IN NATIONAL IDENTITY CREATION}

\author{
МЕСТО КУЛЬТУРНОЙ ПАМЯТИ И ФУНКЦИЯ ПЛАЧА \\ ПИНАРБАШИ В СОЗДАНИИ НАЦИОНАЛЬНОЙ ИДЕНТИЧНОСТИ
}

\author{
Ramazan ERGÖZ** \\ Oğuz DOĞAN***
}

\section{ÖZ}

İnsanoğlu çevresini anlamlandırarak kendisi için bir dünya kurar. Kurulu olan bu dünya düzeninin devam etmesi için kültür üretimi ve bu kültürün gelecek nesillere aktarılması gerekmektedir. Bu aktarımın sürekli bir hal alabilmesi için insan belleğinde kalıcı olması gerekir. Kültürel anlamda belleği bir mekâna çevirebilmek için insani kodların yaşamın her alanında canlı tutulması ve yeni nesillere aktarılması gerekir. İnsanoğlunun hayatında çeşitli geçiş dönemleri vardır. Doğum, evlenme ve ölüm insan hayatının önemli geçiş dönemlerindendir. Geçiş dönemleri etrafinda oluşan inanıș ve ritüeller kültürel belleğin canlı tutulmasında önemli bir yere sahiptir. Ölüm etrafinda da çeşitli kültürel faaliyetlerin ortaya çıtı̆̆ı görülmektedir. Ölüm öncesinde, sırasında ve sonrasında olmak üzere çeşitli aşamalarda ortaya çıkan inanış ve uygulamalar binlerce yıllık kolektif bilinçaltının izlerini taşır. Ölen kişinin ardından yakılan ağıt, insanoğlunun ölümle birlikte kaybettiği bir yakının acısının dışa vurulmuş yansımasıdır. Ağıtlar ölen kişiye bir çeşit veda niteliği taşımakta, o kişinin kısa bir hayat hikâyesini acıklı bir şekilde dile getirmektedir. Aynı zamanda ağıtlarda kültürün izlerini görmek mümkündür. Ağıtlarda günlük yaşamın izlerini, gelenek ve göreneği, sosyal hayatı, coğrafi unsurları vb. birçok unsur yer almaktadır. Ağıtlar milli kimliğin taşıyıcısı olma özelliğine de sahiptir. Acıklı olayların sonucunda ortaya çıkan ağıtlar, bireyin milli kimliğini bulmasına yardımcı olacak kodları içerir. Ağıtlarda gelenek ve görenek, vatan ve dil gibi milli kimliğin ana unsurlarını bulmak mümkündür. Bu bağlamda Pınarbaşı ağıtlarında da bireyin kültürel kimliğine ulaşmasına yardımcı olacak kodlar yer

* $\mathrm{Bu}$ çalışma 10-12 Mayıs 2018 tarihinde düzenlenen I. Pınarbaşı (Aziziye) Sempozyumu'nda sözlü olarak sunulan bildirinin gözden geçirilmiş ve genişletilmiş halidir. ** ORCID: 0000-0002-4513-3574, Dr., Bitlis Eren Üniversitesi, Fen Edebiyat Fakültesi, Türk Dili ve Edebiyatı Bölümü, rergoz@beu.edu.tr

*** ORCID: 0000-0002-7752-8378, Dr., Bitlis Eren Üniversitesi, Fen Edebiyat Fakültesi, Türk Dili ve Edebiyatı Bölümü, odogan@beu.edu.tr 


\title{
Kültürel Bellek Mekânı Ve Milli Kimlik Yaratmada Pınarbaşı Ağıtlarının İşlevi
}

almaktadır. Pınarbaşı ağıtlarında kültüre ve milli kimliğe ait unsurların yoğun bir şekilde yer aldığı görülmektedir. Çalışmamızda ağıtların kültürel belleği ve milli kimliği yaratmadaki işlevi üzerinde durulacak ve Pınarbaşı ağıtları bu bağlamda incelenecektir.

Anahtar Sözcükler: Kültür, Kültürel Bellek, Milli Kimlik, Ağıt, Pınarbaşı.

\begin{abstract}
Human beings make a world for themselves by making sense of their environment. In order for this transfer to be continuous, it must be permanent in human memory. Turning the memory into a place in a cultural sense, human codes should be kept alive in all areas of life and transferred to new generations. There are various transitional periods in human life such as birth, marriage and death. They are essential transitions in human life. Beliefs and rituals formed around the transition periods have an essential place in keeping the cultural memory alive. It is understood that various cultural activities have emerged around death. The beliefs and practices that emerged at various stages before, during and after death bear the traces of thousands of years of the collective subconscious. The lament burned after the deceased is the outward reflection of the pain of a relative lost by humanity with death. The laments are a kind of farewell to the deceased, expressing a short life story of that person pathetically. It is also possible to see the traces of culture in laments. In laments, traces of daily life, tradition and custom, social life, geographical elements, etc. There are many factors. Laments also have the feature of being the bearer of national identity. The laments that result from pathetic events contain codes that will help the individual find his national identity. It is possible to determine the main elements of national identity such as tradition and custom, homeland and language in laments. In this context, there are codes in Pinarbasi laments that will help individuals reach their cultural identity. It is seen that the elements of culture and national identity are intensely included in Pinarbasi laments. In our study, the function of laments in creating a cultural memory and national identity will be emphasised, and Pinarbasi laments will be examined in this context.
\end{abstract}

Keywords: Culture, Cultural memory, National identity, Lament, Pinarbasi.

\section{PЕЗЮМЕ}

Человечество строит для себя мир, понимая свое окружение. Для того, чтобы этот установленный миропорядок продолжался, необходимо производство культуры и передача этой культуры будущим поколениям. Эта передача должна быть постоянной в человеческой памяти, чтобы она могла стать постоянной. Чтобы превратить память в пространство в культурном смысле, человеческие коды должны быть сохранены во всех аспектах жизни и переданы новым поколениям. В жизни человека есть несколько переходных периодов. Рождение, брак и смерть являются важными переходными периодами человеческой жизни. Убеждения и ритуалы, которые формируются вокруг переходных периодов, занимают важное место в поддержании культурной памяти. Повидимому, вокруг смерти также происходят различные культурные мероприятия. Убеждения и практики, возникающие на разных этапах, в том числе до, во время и после смерти, несут следы коллективного подсознания в течение тысяч лет. Плач, сожженный после умершего, является экстравертированным отражением боли близкого человека, которую человечество потеряло вместе со смертью. Плач носит своего рода прощальный характер с умершим, жалко выражая короткую историю жизни этого человека. В то же время можно увидеть следы культуры в плачах. В плаче есть следы повседневной жизни, традиции и обычаи, социальная жизнь, географические элементы и т. д. многие элементы включены. Плач также имеет свойство быть носителем национальной идентичности. Плач, вызванный печальными 
событиями, содержит коды, которые помогут человеку найти свою национальную идентичность. В плаче можно найти основные элементы национальной идентичности, такие как традиции и обычаи, Родина и язык. В связи с этим в источниках также содержатся коды, которые помогут человеку достичь своей культурной идентичности. В плачах пинарбаши, по-видимому, активно участвуют элементы культуры и национальной идентичности. Наше исследование будет сосредоточено на культурной памяти плача и его функции в создании национальной идентичности, и плач Пинарбаши будет изучен в этом контексте.

Ключевые Слова: Культура, Культурная память, Национальная идентичность, стенать, Пинарбаси

\section{GÍRIŞ}

1. A

İnsan ömrünün üç önemli geçiş dönemi vardır. Bunlar; doğum evlenme ve ölümdür. Bu üç dönemin insanlık için en acı olanı ise ölümdür. Ölüm kaçınılmaz bir gerçek olarak insanın karşısında durmaktadır.

Ölüm karşısında insanın acısını ifade etme biçimleri vardır. Bunlardan birisi de ağıt yakmaktır. Ağıt, ölümün acısı ile söylenen ezgili sözlerdir. Birini kaybetmenin acısını söze döken insanoğlu, söz ile acısını hafifletir ve ölen kişiyi anar. Ağıt bir nevi ölen kişinin hayat hikâyesinin dile getirilmesidir. Ağıtta kişinin sağ iken neler yaptığ 1 , neler yapacağ 1 ve neler yapamadığ 1 anlatılır.

Türk kültüründe ağıt ve ağıt söyleme geleneğine İslamiyet öncesi dönemde rastlanmaktadır. Bu dönemde Türk topluluklarında ölen kişinin ardından yuğ adı verilen törenler düzenlenmiştir. Bu törenlerde ölen kişinin acısını dile getirmek için sagu adı verilen şiirler söylenmiştir. Orhun Yazıtlarında geçen sıgıt ve sıgıtçı ifadeleri ağıt söyleme geleneğini gözler önüne serer.

Türk kültüründe oldukça yaygın olan ağıt türü hakkında çeşitli tanımlamalar yapılmaktadır. Şükrü Elçin ağıt için "İnsanoğlunun ölüm karşısında veya canlıcansız bir varlı̆̆ını kaybetme, korku, telaş ve heyecanındaki üzüntülerini, feryatlarını, isyanlarını, talihsizliklerini, düzenli-düzensiz söz ve ezgilerle ifade eden türkülere Batı Türkçesi 'nde umumiyetle 'ă̆ıt' adı verilir. Ağıt söyleyen için 'ă̆ıtçı' sözü yaygınlaşmış ve 'ağıt yakmak' deyimi türemiştir' (Elçin, 2004: 290) demektedir. Esma Şimşek; "A ğıtlar sızlayan kalplerin, dayanılmaz acıların, akan gözyaşlarının, yanık yüreklerin çare arayan feryadıdır." (Şimşek, 1993: 1) diyerek ağıtın ölüm acısını yaşayanların acısını azaltmaya yardımcı olduğunu belirtir. Doğan Kaya ise ağıtı; "başta ölüm olmak üzere ayrllı̆̆ın yahut üzüntünün doğurduğu ıstırap sebebiyle ortaya konulan lirik ve manzum ürün. Şayet ölenler için söyleniyorsa kendisine has makamla terennüm edilir. Söylenen sözler ölenle ilgili düşünce, duygu ve izlenimleri ihtiva eder." (Kaya, 2007: 28) şeklinde tanımlamaktadır. Erdoğan Altınkaynak ağıtın tanımını yaparken konuya daha bütüncül yaklaşmış ve ağıtı; "Konusu ölüm olan, genellikle 8'li hece ölçüsüyle ve aaxa veya xaxa kafiye şemasında, cenaze başında ve devamla yas süresi içerisinde belirli bir törene veya töreye bağlı olarak ve genellikle kadınlar arasında meydana getirilen bir şiir türüdür. Ăğtların meydana geliş mekânı cenaze veya yas evidir."(Altınkaynak, 2015: 45) şeklinde tanımlamıştır. 
Ölüm sonrası tutulan yasın; inkâr, kabul ve uyum olmak üzere üç evresi vardır. $\mathrm{Bu}$ üç evre içerisinde ölen kişinin yakınlarında bazı tutum ve davranışlar görülür. Örneğin; uyuşukluk, durumun gerçek olduğuna inanmama, ölenin hasretini çekmek, ağlama ve kızgınlık, doktorlara ve hastane personeline kızma, suçluluk, aşırı enerji, duygu dengesizliği, her olayı ölen kişi ile açıklama, fiziksel ve ruhsal problemler, ölen kişinin yakınlarında ölümün yol açtığı olumsuz etkiler olarak sıkça görülen durumlardır (Baltaş, 2000: 158-160). Ölüm olayı kabullenilmesi zor ve acı bir süreçtir. Bir yakınını kaybeden aile bireyleri ve toplum, ölümü kabullenmekte zorluk yaşarlar. Bu bağlamda ağıtlar, ölümü kabullenmede önemli bir işleve sahiptir. Ölüm, kişiler üzerinde fiziksel etkilerinden ziyade ruhsal anlamda yıkıcı etkilere neden olur. Bireylerin ölüm karşısında sessizliğe bürünmeleri, ruhsal bir çöküntüye sebebiyet verebilir. Ağıt, yaşanan acının dışa yansıması olarak düşünüldügünde, ölünün yakınlarının ruhsal anlamda da rahatlamasını sağlar. Toplumların en büyük ruhsal kırılmalarının büyük felaketler sonucunda yaşandığı görülür. Ölüm olayının ardından kişilerin içinde bulundukları ruhsal bunalımdan kurtulamayarak intihara varan süreçler yaşandığ gözlemlenebilmektedir. Bu bağlamda ağıt, bireysel ve toplumsal psikolojinin sağlıklı kalmasında önemli bir yere sahiptir. Ağıtlar, yatay boyutta bireysel ve toplumsal psikolojinin korunmasını sağlamasının yanında; dikey boyutta bağlı bulunduğu toplumun kültürel belleğinin yaşatılmasını sağlayan tarihi, kültürel ve sosyal kodları gün yüzüne çıkartır. Ağıtlar toplumun unutmaya yüz tuttuğu değerleri güncelleyerek yeniden gün yüzüne çıkartır. Ölümün yol açtığı üzüntü nedeniyle algıları dış dünyaya kapanan insanlar için ağıtta söylenen her söz, bellekte kalıcı bir yer edinir.

\section{Kültürel Bellek ve Milli Kimlik}

Bireylerin kendilerini ifade edebilmeleri için gereklilik duyduğu bazı durumlar vardır. Bunların en başında geleni ise onları tanımlayan kimlikleridir. Temel anlamda kimlik, "bir varlığın aynılık olarak tanımlanabilir ve tanınabilir kılan özellikleri ile açıklanır" (Çağırkan, 2016: 2616). "En yalın tanımıyla kimlik, kişilerin, grupların, toplum veya toplulukların "Kimsiniz, kimlerdensiniz?" sorusuna verdikleri yanıt ya da yanıtlardır" (Güvenç, 1995: 3). Gün içerisinde karşılaştığımız insanlara sorduğumuz sorular ve aldığımız yanıtlarla iletişim için önemli olan ilk adımı tamamlarız. Bünyesinde farklı alt başlıklar barındıran kimlik kişilerin dünya üzerinde anlamlı bir bütün olmasını sağlar. Fakat "Bütün kimlikler, bir toplumsal ilişkiler sistemi içinde oluşur ve birbirlerini karşıllkkl tanımaları gerekir. Kimlik bir "nesne" olarak değil, "bir simgeler ve ilişkiler sistemi" olarak düşünülmelidir"(Morley ve Robins, 1997: 74). Kimlik simgeler ve ilişkiler sistemi olarak düşünüldüğünde millilik özelliğine bürünmek zorunda kalır. Çünkü bir toplumun özel anlam yüklediği ve meydana getirdiği sistem var olduğu toplumun geleneksek özelliklerini taşır. Her toplumun kendisine has bir yaşam sistematiği olduğu gerçeğinden yola çıktı̆̆ımızda milli kimliğin varlığı karşımıza çıkacaktır. "Tarihî bir toprağı/ülkeyi, ortak mitleri ve tarihî belleği, kitleyi bir kamu kültürünü, ortak bir ekonomiyi, ortak yasal hak ve görevleri paylaşan bir insan topluluğunun" (Smith, 1994: 75) adı olan milletin oluşması içinde milli kimlik gereklidir. 


\section{Ramazan ERGÖZ - Oğuz DOĞAN}

Kültür "1.isim Tarihsel, toplumsal gelişme süreci içinde yaratılan bütün maddi ve manevi değerler ile bunlar yaratmada, sonraki nesillere iletmede kullanılan, insanın doğal ve toplumsal çevresine egemenliğinin ölçüsünü gösteren araçların bütünü, hars, ekin. 2. Bir topluma veya halk topluluğuna özgü düşünce ve sanat eserlerinin bütünü 3. Muhakeme, zevk ve eleştirme yeteneklerinin ögrenim ve yaşantılar yoluyla gelişstirilmiş olan biçimi. 4.Bireyin kazandiğı bilgi." (URL-1) olarak farklı şekillerde tanımlanmaktadır.

Halk kültürü bir milletin sahip olduğu, dil, kültür, duygu ve düşünce değerlerinin toplamından oluşur. Bir halkın birlikte oluşturduğu ve geçmişten bugüne çeşitli değişiklikler geçirmiş olsa da günümüze kadar gelen bu değerler bütünü, içerisinde yaşatıldığı halkı birbirine bağlayan kültürel bellek mekânlarını oluşturur. Yeni doğan bireyler sahip olunan bu kültürü zamanla öğrenerek toplumun bir parçası haline gelir. Türk halk kültürü Orta Asya'dan Anadolu'ya uzanan yaşam sürecinde belirli dönemlerde etkileşim içinde olduğu kültür çevrelerinden etkilenmiş olsa da kendine özgü bir kültür hazinesine sahiptir. Bu kültür hazinesi asırlardan beri yapılan uygulamalar ile gelecek nesillere aktarılmakta ve yaşatılmaktadır.

Bellek "denince insanın aklına genellikle bir iç olgu gelir ve bunun mekânı bireyin beynidir, yani belleğin beyin fizyolojisiyle, nöroloji ve psikolojiyle ilgili olduğu düşünülür, ama tarihsel kültür bilimi ile bir ilgisi yoktur. Oysa bu belleğin neleri içerdiğini, bu içeriklerin organize edilişinin ve ne kadar süre ile muhafaza edileceğini bireyin kapasitesi ve yöneliminden çok, dış koşullar, yani toplumsal ve kültürel çerçevenin koşulları belirler" (Assmann, 2015: 26-27).

Jann Assmann, mimetik bellek, nesneler belleği, dil ve iletişim ve anlam aktarımı olmak üzere belleğin dört farklı boyutu olduğunu belirtir;

1. Mimetik bellek. Davranış, taklit veya deneyimsel bellek. Bu bellek boyutunda davranışlar taklit sonucu kazanılır. Günlük yaşamımızda davranışlarımız, taklit etme geleneğine bağlı olarak alışkanlık ve kurallara dayanmaktadir.

2. Nesneler Belleği. İnsan hayatı boyunca çeşitli nesnelerle çevrelenmiştir. Bu nesneler kişinin yansımasıdır. İnsana geçmişini, atalarını hatırlatır.

3. Dil ve iletişim: İletişimsel Bellek. İnsan dil sayesinde başka insanlar anlaşabilir ve sosyal bir varlık olur. Dil yeteneği ve anlaşma yeteneği insanın kendi çabası ile geliştirebileceği bir yetenek değildir. Bunun için diş dünya ile etkileşim halinde olmalıdır.

4. Anlam aktarımı: Kültürel bellek. Bu bellek alanı mimetik, nesneler ve dil ve iletişim belleğinin bütünlük içine bulunduğu bir bellek alanıdır. Rutin olarak tekrarlanan davranışlar geleneksel boyuta ulaştığı zaman mimetik belleğin boyutundan çıkar ve kültürel belleğin sınırları içerisinde kendisine yer bulur. Nesneler de amaca yönelik olmanın dışında anlam kazanmasıyla içten dişa doğru yönelen bir değer dizgesi kazanırsa nesneler belleğinin sınırlarını aşar ve kültürel belleğin varlık alanına girer. Dil ve iletişim belleği de yazı sayesinde kültürel bir anlam ve bellek kazanır. Yazı sayesinde bireysel belleğin sınırlarının dışına çıkılabildi. Kültürel bellek gelenek ve iletişimden beslenir ama onlar tarafindan belirlenmez (Assmann, 2015: 26-28). 
"Kültürel bellek ile kastedilen insan belleğinin dış boyutudur." Kişisel bellekten ziyade toplumsal bellek kültürel belleğin sınırları içerisinde yer alır. İnsan öncelikli olarak kişisel bir belleğe sahiptir ve bu bellek alanı insanın kendi yaşamı ile sınırlıdır. İnsanın hayatı boyunca kendi içi dünyasında biriktirdiği bir anılar magmasıdır. Oysa kültürel bellek ile dışa açılan ve bireyden topluma uzanan daha kapsayıcı geniş bir bellek alanı ortaya çıkmaktadır. Kişisel bellek bireyin kendisine ait olduğu için kendisiyle birlikte yok olup gitmektedir. Oysaki kültürel bellek geleneksel boyuta ulaşmış bir davranışlar ve ritüeller dünyasına sahiptir. $\mathrm{Bu}$ da kültürel belleğin kuşaktan kuşağa aktarılmasını sağlar. Aynı şekilde nesneler belleği de kişisel bir boyuttan kolektif bir hale dönüşünce nesnelerin dişa dönük anlamları sembolleşmektedir. Bu da toplumu bir arada tutan ülkü eğer bellek mekânlarını ortaya çıartır "Kişinin kendini çevreleyen şeyler dünyasında yitip gitmemesi için onun, tarihselliğini sağlayan bellek mekânlarına tutunması ve orada kurduğu kendilik bilinci ile hem uzamsal boyutta dünya ile hem de zamansal boyutta toplumsal geçmişiyle bağlantıya geçmesi kaçınılmaz bir gerekliliktir. Bu bağlamda bellek mekânları, mitik kahraman Antheus'un toprağı gibi, kendisiyle temasa geçildiğinde öleni dirilten bir tinsel varoluş alanıdır. Yaşadıklarımız, düşlediklerimiz gibi unuttuklarımızın da içimizdeki toplanma merkezi olan bu tinsel varoluş alanları (bellek mekânları), kendilik bilinci kurmanın en temel çıkış noktasıdır"(Korkmaz, 2008: 31).

3. Kültürel Bellek Mekânı Yaratmada Pınarbaşı Ağıtlarının İşlevi

İnsan çevresiyle kurduğu ilişkide nesnelere anlam ve değer katarak onlarla olan ilişkisini fiziksel anlamdan tinsel boyuta taşır. Böylelikle zamansal ve mekânsal anlamda sınırlı olan insan nesli kendisini sonsuza açar. İnsanın yaşadığı çevrede oluşturduğu kültür bu sonsuzluk dairesi içerisinde bir sonraki nesle devredilerek yaşatılır. Çevresine anlam ve değer katarak yaşadığı yeri dünyalaştıran insanoğlu yaşadığ 1 coğrafyanın bilgisine de sahip olmak ister. İnsan yaşadığı yeri gerçek anlamda yurt edinmek/ vatanlaştırmak için üzerinde yaşadığı toprağın, dağların, suların bilgisine de sahip olmalıdır. Ancak bu sayede coğrafya yurt edinilir. Bu anlamda kültür insanın yaşadığı yeri yurt edinmesindeki en önemli üretimdir. Doğumdan ölüme uzanan insan ömründe doğumdan başlayarak ölüme kadar çeşitli uygulamalar ve inanışlar vardır. Bu uygulamalar nesilden nesle aktarılarak birer gelenek haline gelir. Bir sonraki neslin bir önceki nesilden davranış ve taklit yoluyla öğrendiği bu uygulamalar zamanla gelenekselleșerek mimetik bellek alanından kültürel bellek alanına girer. Kişisel bellekten kolektif belleğe dönüşür.

Halk edebiyatının sözlü ürünleri kültürel belleğin en önemli aktarıcılarından biridir. Çünkü insan yaşamının mikro ölçekli birer yansıması olan türküler, maniler, ninniler ve ağıtlar kültürden ve insandan bağımsız değildir. Merkezinde insanın olduğu bu anlatılar kültürü bir sonraki nesle taşıyarak kültürel bellek aktarıcısı olurlar.

Hayatın geçiş dönemlerinden biri olan ölüm hadisesi sonrasında söylenen ağıtlar, kültürel belleğin aktarımında önemli bir işleve sahiptir. Ölen kişinin ardından söylenen ve ölüm acısının dışa yansıması olan ağıt, başlangıçta kişisel belleğin 
izlerini taşımakla birlikte, toplumla paylaşılması ve çevreye ait kültürel unsurların ağıta işlenmesi ile kolektif belleğe taşınır ve kültürel belleğin aktarıcısı işlevini görür.

Belleğin güçlenmesi için belleğe kaydedilen şeylerin sık sık tekrar edilmesi gerekmektedir. Sözlü kültür ürünleri bellekte canlı kalabilmek için sık sık tekrar edilmeye muhtaçtır. Bu tekrarlar belleği güçlendirir. Sözlü kültürde tekrar edilmeyen şeyler unutulmaya ve yok olmaya mahkûmdur. Bu nedenle sözlü kültür ürünleri çok sık tekrarlanarak bellekte kalıcı bir yer edinmesi sağlanır. Başka bir ifadeyle yazılı kültür belleğin tembelleşmesine neden olurken; sözlü kültür -biraz da mecburiyetten- belleğin güçlenmesini sağlar. $\mathrm{Bu}$ bağlamda insan ömrünün kaçınılmaz bir sonu olan ölümlerin daimi oluşu ve bu ölümlerin ardından ağıt yakılması belleği güçlendirir. Yakılan ağıtların sık sık tekrar edilmesi kültürel belleğin canlı tutulmasını sağlar. Nitekim Pınarbaşı'nda da "ăğtlar ilk söylendiği anan itibaren çevrede bulunan kadınlar veya genç kızlar tarafindan bir ses kayıt aract hassasiyetinde ezberlenir/ezberlettirilir ve özel toplantılarda hall-kilim tezgâhları başında ağrişmelerde (kadınlar arasındaki imece) çamaşır ve yün yıkamalarda, dügüunlerde, nişanlarda, koyun sağımlarında, yayla yollarında vb. gibi toplu yapılan hareketlerde tekrar edilir" (Altınkaynak, 2015: 147). Pınarbaşı ağıtları adeta sosyal yaşamın bir parçası haline gelmiştir. Toplumun her türlü sosyal organizasyonunda ağıtların söyleniyor olması, sözlü gelenekte ağıtları canlı tutmakla birlikte, ağıtların aktardığı kültürel bilgiyi gelecek kuşaklara aktarmayı da sağlamaktadır. Böylece ağıtların içerisinde bulunan ve kültürel belleğe işlenen kültür ürünleri toplumsal kolektif bilinçte yaşatılmaktadır.

Pınarbaşı ağıtlarında maddi kültür ürünlerini, giyim-kuşam, geçiş dönemlerinden ölüm ve düğün, adak adama, halk inanışları, coğrafi mekânları ve tarihi şahsiyetleri bulmak mümkündür. Bu bağlamda ağıtlar Pınarbaşı ilçesinin bir kültür ve tarih envanteri görevini de görmektedir. Geçmişten günümüze gelen birçok geleneği, ilçe ve köylerin eski adlarını, tarihi olayları, günlük hayatı, sosyal yaşamı ağıtlardan öğrenmek mümkündür.

Merkezinde insanın anlatıldığı ağıtlar, ölen kişiyi unutmamayı ve sözlü kültürde canlı tutmayı sağlamakla birlikte, "ölümlü insanı, toplumsal tine taşlyarak ölümsüzlüğe kavuşturan bir araçtır”(Korkmaz, 2008: 80).

Pınarbaşı ağıtlarında ölüm ile ilgili olarak uygulama ve inanışlara rastlamak mümkündür. Cenazenin götürülme vakti ve tabutun üzerine örtülen eşyalar aşağıdaki ağıtta şu şekilde dile getirilir:

Şöyle gardaş gördünüz mü

Dar vahitta götürdüler

Ben üsdüne örtdüm hal1

Guru yere yatırd1lar (Altınkaynak, 2015: 322)

Anadolu'nun birçok yerinde ölünün gömülme saati ile ilgili farklı uygulamalara rastlamak mümkündür. Bazı yerlerde ölü, uzakta olan bir yakını gelinceye kadar bekletilirken bazı yerlerde ise bir an önce defnedilmeye çalış1lır. Bu ağıtta Pınarbaşı yöresinde ölünün dar vakitte kaldırılıp defin işlemi için götürüldüğü belirtilmektedir. Bununla birlikte ölümden sonra yapılan işlemlerden biri de tabutun 


\section{Kültürel Bellek Mekânı Ve Milli Kimlik Yaratmada Pınarbaşı Ağıtlarının İşlevi}

üzerine örtülen eşyalardır. Ağıtta belirtildiği üzere ölünün üzerine halı örtülmüştür. $\mathrm{Bu}$ Anadolu'da sıkça rastlanan bir uygulamadır.

Ölüm acısının ardından yas tutma geleneği vardır. Yas tutma sürecinde kara giyinmek de yasın belirtilerinden biridir. Bu uygulamaya Pınarbaşı yöresinde de rastlanır. Ağıtlarda da bu durum dile getirilir:

Musa çoh yellin ağliyor

Anşa atın gara bağlıyor

Sırtına gabıdın giymiş

Gardaşım gelir sanıyor (Altınkaynak, 2015: 452)

Pınarbaşı'nın Hasırcı köyünden olan Mustafa Korkmaz ameliyat sırasında vefat eder. Ölümünün ardından Mustafa için ağıt yakılır. Yukarıdaki ağıtta ölenin kardeşi Musa çok ağlamakta, kız kardeşi de karalar bağlamaktadır. Karalar bağlamak ölüm acısının en dikkat çekici hallerindendir. Binlerce yıllık bir gelenek bu ağıtta tekrar hatırlanmış kolektif bilinçaltından, bilinç düzeyine çıkartılmış ve kültürel belleğe işlenmiştir.

Ağıtlarda gördüğümüz bir diğer ölüm sonrası uygulama ise ölünün defninin ardından yapılan talkın işlemidir. Pınarbaşı Pazarören kasabasından Mithat'ın ağıtında bu uygulama anlatılır:

Azıcık da ağar alın

Gan döşşeğa bulaşmasin

Din talkını verirkene

Oğlum dilin dolaşmasın (Altınkaynak, 2015: 539)

Talkın, öğüt ve telkin anlamına gelmektedir. İslamiyet’te ölen kişinin kabre konulmasının ardından sorgu meleklerinin gelip ona sorular soracağına inanılır. Cenazenin defnedilmesinin ardından imam tarafindan verilen talkın, melekler tarafından sorulan sorulara mümin kişinin vermesi gereken yanıtların hatırlatılması işlemidir. Bu ağıtta ölüm sonrasındaki bu önemli uygulama hatırlatılmaktadır.

İnsanın yaşadığı çevreyi bilip tanıması ve onunla bağ kurabilmesi için yaşadığı yere verilen adları da bilmesi gerekmektedir. Özellikle de kırsal bölgelerde belirli bölgelere verilen adlar genellikle atalarımızın binlerce yıllık bilgi birikiminin ve yaşanmışlığın bir sonucu olmaktadır. Bu nedenle insanın yaşadığı yerin dağlarının, ovalarının, sularının, tepelerinin ve mevkilerinin adını bilmesi onu tarihselliğine ve atalarının binlerce yıllık birikimine bağlar. Pınarbaşı ağıtlarında da yer adlarının yoğun bir şekilde yer aldığı görülmektedir. Bu durum ağıtlar sayesinde insanın yaşadığı bölgenin bilgisine sahip olmasını sağlar. Bu yer adları kültürel belleğe işlenmekle gelecek nesillere ulaşma imkânı bulur.

Pınarbaşı Pulpınar Köyünden önemli bir şahsiyet olan Halloğlu Anber Ağa'nın ağıtında Pınarbaşı yöresine ait birçok yer adı geçmektedir:

Tucar'dan duman kahıyor

Anam oğluna bahıyor

Anam oğlu su isdemiş

Savrun Penzefir ahıyor (Altınkaynak, 2015: 277)

İnsan içinde yaşadığ 1 çevrenin unsurlarını türkülere, ninnilere, manilere ve ağıtlara katar. Derdini ve üzüntüsünü anlatmada onları da birer aracı kılar. Ağıtlarda 
da ölen kişinin yaşadığı çevrenin unsurları yer alır. Belirli mevkiler ağıtlar da dile getirilir. Yukarıdaki dörtlükte Tucar ve Savrun adında iki yer ismi verilmiştir. "Tucar, Kadirli'ye beş km. Akşamat köyü yakınında bir mevkidir. Bitiş̧iğinde Tucar mezarlığ diye bir yer vardır. Bu mezarlık kastedilmektedir." (Altınkaynak, 2015: 390). Savrun ise Kadirli' yi ikiye ayıran bir irmaktır.

Ahmed Ağa'nın ağıtında da Sarıçek, Sıçanlı ve Köt'oluh denilen yerler dile getirilir.

\author{
Bahele bre Duduma \\ Bah gardaşın boyununa \\ Sarıçek de gurt mu daldı \\ Gardaşıyın goyununa (Altınkaynak, 2015: 280)
}

Pınarbaşı yöresinde dağlar ve yaylalar yoğun olarak bulunmaktadır. Anlatılarda bu coğrafi mekânlar sıklıkla kullanılır. Ahmed Ağa ağıtında da görüldüğü üzere Sarıçek denilen ve Sarıçiçek isminin kısaltması olan bu yer bir yayladır. Ağıtın bir başka dörtlüğünde yine dağ ve yayla adı olan Sıçanlı'dan bahsedilir.

Duymuyon mu ne daniyor

Gara çadır gurul oldu

Anam babayın sürüsü

Sıçanlı'da sulanırdı. (Altınkaynak, 2015: 280)

Hayvancılıkla uğraşılan bölgelerde insanların sözlü kültürlerinde dağ ve yayla imgelerinin yoğun olarak yer aldığı görülmektedir. Yaşam biçimi anlatı türlerine de bir şekilde yansımaktadır. Böylelikle kültürel bellekte coğrafi yer adları yer edinmekte ve yaşatılmaktadır.

Kahd1 toprahların garı

Gene dağlar giyer donu

Yaylayı canı isdemiş

Köt'oluh'dan dönmüş geri. (Altınkaynak, 2015: 286)

"Köt'oluh, Keltepe köyünde yayla yolu üzerinde bir mevki adı(dır)" (Altınkaynak, 2015: 382). Mevki adları insanın kendisini yaşadığı coğrafyada güvende hissetmesini sağlar. Daha öncede söylemiş olduğumuz gibi yaşadığımız coğrafyanın bilgisine sahip olabilmek demek o topraklara gerçek anlamda sahip olabilmek demektir. Bu nedenle mevki adları gelişigüzel konulmuş isim tercihlerinden ziyade o bölgede yaşayan insanların kültürel kodlarından da izler taşır. Bu bağlamda ağıtlarda yer alan yer adlarını kültürel belleğin önemli bir değeri olarak görmek gereklidir. İnsanın çevresiyle kuracağı güvenli ontik ilişkide bu bakımdan ağıtlar önemli bir kültürel işlevi yerine getirmektedirler.

Ağıtlarda insan hazinelerinin biyografilerine de yer verildiği görülür. Yaşadığ1 toplumun önemli şahsiyetleri, ölümlerinin ardından yakılan ağıtlar ile kolektif belleğe kazınırlar. Ağıtlar sayesinde toplumsal hafızanın derinliklerinde bir 


\section{Kültürel Bellek Mekânı Ve Milli Kimlik Yaratmada Pınarbaşı Ağıtlarının İşlevi}

ömür boyu saklı kalır ve yaşatılırlar. Bu insan hazinelerinden biri de Anber Ağa'dır. Pınarbaşı'nın Pulpınar köyünden olan Anber Ağa, belki de üzerine bu ağıt yakılmasaydı birçoğumuzun adını dahi bilmediği bir kişi olarak sadece birkaç kişi tarafından hatırlanacaktı. Ancak bu ağıt sayesinde Anber Ağa, tarihi bir şahsiyet olarak kültürel belleğimizde yaşatılmaktadır. Ağıtta şu dizelere yer verilir.

Şu efeyi biliyon mu

Avşarın Anber Ağası

Dizlek çanı çalınıyor

Geliyor tülü mayası (Altınkaynak, 2015: 277)

$\mathrm{Bu}$ ağıtı Anber Ağa’nın ani ölümü üzerine kız kardeşleri yakmıştır. Anber Ağa, yaşadı zaman dilimi içerisinde çevresi tarafindan sevilen, varlıklı bir kişi olarak bilinir (Altınkaynak, 2015: 390).

Kültürümüzün önemli ögelerinden biri de adak adamadır. İstenilen bir şeyin gerçekleşmesi durumunda bazı şeyler vaat edilir ve kişinin dileği yerine gelince adağını yerine getirir. Kansere yakalanan ve iyileşemeyerek vefat eden İzzet Kandemir'in ağıtında bu dertten kurtulursa kurban adanmaktadır:

Pınarbaşı açılsın da

Gardaşım edici dügün

Ağer bundan gurtulursa

Hall'ağam kesici goyun (Altınkaynak, 2015: 434)

Ölen kişinin kız kardeşleri tarafından yakılan bu ağıtta, kanser hastalığına yakalanan kişinin iyileşmesi durumunda yapılacaklar dile getirilmektedir.

Pınarbaşı ağıtlarında halk inanışlarını da bulmak mümkündür. Halk inanışları insanların dünyaya kattıkları anlam ve değerdir. İnsanoğlu ilkel zamanlarda doğa ile mücadelesinde onu kendisi için bir koruyucu kılmış, dağların, suların vb. unsurların bir ruhu olduğuna inanmıştır. Zamanla da bu nesnelere saygı duymuş ve onun kendisi için koruyucu olduğuna inanmıştır. Halk inanışları zaman içinde değişkenlik göstermekle birlikte özündeki doğaya ve canlılara saygılı olma, ülkü değer davranış kodlarını koruma gibi inanışları korumuştur.

Anadolu halk inanışları açısından zengin bir birikime sahiptir. Bu birikim ağıtlara da yansır. Aşağıdaki ağıtta ülkü değer davranış kodlarına sahip bireyin cennetin kapılarını açacağı belirtilir:

Birikin dertli olanlar

Yedi bebağa galanlar

Cennetin kapısın açar oyyyy

Öğsüze ekmek verenler (Altınkaynak, 2015: 513)

Türk toplumu sosyal anlamda yardımlaşmayı seven, darda kalana yardım eden bir toplumdur. Bu ülkü davranışın da bir ödülü olduğuna inanılır. Yukarıdaki dörtlükte öksüzlere ekmek verenlerin cennetin kapısını açacağı belirtilir. Dini temelleri de olan öksüze yardım etmenin sevap olduğu inanışı, zaman içerisinde sosyal anlamda da bir yardımlaşma aracı olmuştur. Ağıtlar bu insani davranışı içerisinde barındırarak aynı zamanda toplumun eğiticisi olma rolünü de üstlenir. 


\section{Ramazan ERGÖZ - Oğuz DOĞAN}

Ağıtlarda günlük yaşamdan izler bulmak mümkündür. Çocuk oyunları ve eğlencelerde oynanan oyunlar da ağıtlarda yer alır. Ağıt acıklı bir olay neticesinde ortaya çıkmasına karşın, insan ömrünün mutlu ve eğlenceli zamanlarının da olduğuna dair göndermeler içerir. Ölen kişinin ardında bıraktıkları vardır. Çocuklar da geriye kalanlardandır. Telli Efendi'nin ağıtında ağıt yakılanlardan birinin oğlu anlatılır:

Kazim'inin ahlı yetmez

İçerde oynuyor aşıh

Sağaya çark deyinceğaz

Şiforun tebdili şaşıh (Altınkaynak, 2015: 510)

Yukarıdaki dizelerde çocukların oynamış oldukları aşık oyunu anlatılır. Aşık oyunu tarihi bir Türk oyunudur. Koyunların ve keçilerin arka bacaklarında bulunan bir kemik parçasıyla oynanır. Bu oyun misket oyununa benzemektedir.

Büyüklerin oynadığı oyunlar da ağıtlarda geçer. Değnek oyunu da bunlardan biridir:

Siradan'da oynar deynek

Gana belenmiş köynağa

Nasıl gıydın itin dölü

Ziya elimin deynağa (Altınkaynak, 2015: 544)

Ağıtlarda ölen kişinin hayatta iken yaptıkları anlatır. Sıradan köyünden Ziya Bey için yakılan ağıtta Ziya Bey'in değnek oyunu oynadığından bahsedilir. Değnek oyunu cirit oyununa benzer bir oyundur. Değnek oyununun ciritten farkı oyuncuların ellerindeki ciridi birbirlerine değil, iki direk arasına gerilen bir ipin üzerinden aşırtmaya çalışmalarıdır. Bu nedenle bu oyuna bazı bölgelerde değnek aşırma oyunu da denilmektedir.

Ağıtlar genel olarak kadınlar tarafından icra edilir. Bu yüzden ağıtlarda yemek ve giyim-kuşam kültürü hakkında bilgiler sıklıkla yer alır. Pınarbaş1 ağıtlarında da giyim kuşam kültürünün izleri yoğun olarak görülür. Birçoğu günümüzde kullanılmayan, yaşlıların çeyiz sandıklarında birer hatıra olarak sakladıkları giysiler ağıtlar da bir zamanın önemli giyim kuşam kültürü ögeleri olarak dile getirilir. A $\breve{g}$ yağlık, heril domanı, ağ işlik bu giyim kuşam ürünlerinden sadece birkaçıdır:

A $\breve{g}$ yağlık sarar başına

Hayali düşer garşıma

İsmail'im daha cahil

Ölüm ne düşen peşine (Altınkaynak, 2015: 383)

Ağıtlarda giyim kuşam kültürünün izlerinin bulunmasında ölen kişinin günlük yaşamından izlerin de paylaşılması önemli bir nedendir. Ağıtçı ölen kişinin günlük yaşamda nasıl giyindiğine ağıtında yer verir. bahsedilir.

Pınarbaşı ağıtlarında heril domanı denilen ince ipekli bir elbiseden de

Çoh gördüm iyi günümü

Giyerdim heril domanı

Ben gardaşa ağliyorum 


\section{Kültürel Bellek Mekânı Ve Milli Kimlik Yaratmada Pınarbaşı Ağıtlarının İşlevi}

Nediyim elin oğlunu (Altınkaynak, 2015: 390)

\section{Milli Kimlik Yaratmada Pınarbaşı Ağıtlarının İșlevi}

İlk önce Avrupa'da daha sonra ise dünyanın farklı toplumlarında millet olma bilincini oluşturmak amaciyla halka ait olan kültürel değerlere yönelme olmuştur. Bunun sonucunda folklor biliminin temelleri de atılmıştır. Halkın oluşturduğu sözlü kültür ürünleri ve gelenekleri milliyet bilincini artırmak maksadıyla sürekli olarak kullanılmıştır. Çünkü kimlik, kültürün içerisinde barınır ve şekillenir. Bu şekilde birey hayallerini, arzularını, yaşama şeklini ve en önemlisi kendisini tanıyarak hayattaki duruşunu ve yerini bilir. Aslında kültür toplumun kimliğini meydana getirir. Kimlik sadece bit topluma veya millete bağlı olmak değildir aynı zamanda topluluğun diğer bireyleriyle ortak bir kültüre sahip olmaktır. "Kültürün iki yönü, yani kuralcı ve anlatısal, yönlendirici ve nakledici yönü bireylere "biz" deme imkânı veren kimlik ve aidiyet temellerini yaratır. Tek tek bireyleri böyle bir "biz "de birleştiren, bir yandan ortak kurallar ve değerlere bağlllık, öte yandan ortak yaşanmış geçmişin anılarına dayanan, ortak bilgi ve kendini algılayış biçiminin oluşturduğu bağlayıcı yapıdır" (Asmann, 2015: 23). Türk kimliğinin yüzyıllardır teşekkül etmesinin temelinde halka ait olan ve milli hafızasında saklı olan kültürel değerler yatmaktadır. Türklerin ilk yazılı belgelerinde dahi milli bilincin izlerini görmek mümkündür. Kültür ve kimlik milletle varlığını devam ettirerek gelecek kuşaklara doğru yolculuğuna devam eder. Bu yolculuk farklı sözlü kültür ürünleri vasıtasıyla sağlanmaktadır. Ağıtlar, milli kimliği besleyen önemli sözlü anlatı türlerindendir. "Ağıt denilince aklımıza hemen "ölüm” gelir. Oysa savaş, yangın, sel, deprem gibi tabii afetler üzerine; çeşitli kaza ve hastalıklara; askere veya gurbete gönderilen yakınlara; kaybedilen bir eşya yahut hayvanlara da ağıtların söylendiği bir gerçektir" (Şimşek, 1993: 1) Tanımlamadan da anlaşlacağı üzere ağıt tür olarak bünyesinde zengin bir yapı barındırmaktadır. Bu zenginliğin içerisindeki milli unsurlar ise milli kimliği meydana getirir. Gurbete giden birisinin geride bıraktığı vatanına olan duygularını yoğun bir şekilde ağıtlaştırması ya da şehit olan askere yazılan ağıdın etkisinin toplum hafızasında unutulan değerleri hatırlatması türün milli bilinci meydana getirme işlevini göstermesi açısından önemlidir. Çanakkale ruhunu gelecek nesillerin bilincinde canlı tutmak amaciyla Çanakkale Ağıdı'nın sürekli işlenmesi bu durumlardan kaynaklanmaktadır. Pınarbaşı ağıt yakma geleneği açısından önemlidir. Ağıtların konu çeşitliliği göze çarpan bir diğer noktadır. Milli konular üzerine yakılan ağıtların sayısal çoğunluğu bu ağıtların kimlik oluşturması bakımından değerini artırmaktadır.

Sarıkamış Harekâtı öncesi ve sonrası gelişen olaylarla Türk toplumunun bilincinde derin kırılmalara yol açmıştır. Vatan müdafaası için on binlerce Türk askeri donarak şehit olmuştur. Geride kalanlar ve cephede sevdiklerinin hatırasıyla mücadele edenlerin dillerinden dökülenler ağıtlar yoluyla günümüze kadar gelmiştir. Kayseri'nin Pınarbaşı ilçesinden de bu harekâta katılan askere yakılan ă̆ıtlar vardır. Bunlar zaman içerisinde halkın hafizasında işlenerek milli hisler canlı tutulmaya çalışılmıştır. 
İki galdırın bayrağı

Çifte donatın tülüyü

Töbe amandan almiyor

Azarlar çoban Ali (Altınkaynak, 2015: 252)

Pınarbaşı'nın Küçük Harmanlı Köyü 'ünden Sarıkamış Harekâtına katılan ve cephede şehit olan on üç gencin ardından yazılan bu ağıtta dönemin ruhundan yararlanılmıştır. Böylelikle tarihsel olaylar milli bilinci kalıcı olarak kayıt edilmiştir. Bir diğer Sarıkamış ağıtı da;

Sarıgamış ne aralı

Kim ölmüş kimi yaralı

Bunu duymuş varmıyıdı

Yalan dünya kurulalı (Altınkaynak, 2015: 253)

Bölge insanı üzerinde derin etkileri olan Sarıkamış Harekâtına bölgedeki hemen hemen bütün ailelerden asker gitmiştir. Bu gidişlerin ardından duyulan üzüntü ve sonrasında geri dönüşlerin olmaması bölge insanın ruh derinliklerinde ağıtlaşan duyguların ortaya çıkmasına sebebiyet vermiştir.

Gine önü gış geliyor

Bilmiyene hoş geliyor

Sargışla'ya giden gağnı

Dolu gedip boş geliyor (Altınkaynak, 2015: 253)

Cepheye giden askerlerin vatan müdafaasına giderken herhangi bir tereddütleri ve korkuları yoktur. Karşısında silah bakımından üstün olan Rus ordusundan korkusu olmayan askerin soğuklardan dolayı şehit olması toplumu derinden etkileyen en önemli durumdur.

Aziziye baba yurdum

Gafgasya'ya tabya gurdum

Benim gorhum Urus değal

Garagışa gurban verdim (Altınkaynak, 2015: 254)

Pınarbaşı bölgesinde yakılan ağıtların içeriğinde milli kimliği pekiştirici ve yerelden genele doğru ilerleyen bir kahramanlık durumu vardır. Yukarıdaki dörtlükte düşmandan duyulan bir korkunun olmadığı sadece hava şartlarına verilen şehitlerden bahsetmektedir. Silah bakımından kendisinden fazlaca güçlü olan düşmandan korkulmamasının kaynağı toplumun içinde bulunan milli ruhtan kaynaklanmaktadır. $\mathrm{Bu}$ durumda ağıtların içerisinde yer almıştır.

Askerlik her Türk vatandaşının yapması gereken zorunlu bir hizmettir. Ancak bu durum Pınarbaşı'ndan zorunluluktan ziyade gönüllülük derecesindedir. 


\title{
Kültürel Bellek Mekânı Ve Milli Kimlik Yaratmada Pınarbaşı Ağıtlarının İşlevi
}

Bunu askere gidip dönmeyen ve şehit olanlar üzerine yazılan ağıtlardan anlamak mümkündür.

\author{
Adanı'ya vardım 1dı \\ Dirambetler datlı öter \\ Gücücükden esger etdim \\ Guzum goğuşunda yatar (Altınkaynak, 2015: 261)
}

Milli değerlere bağlı olan yöre insanlarından dul bir kadın tek oğlunu da subay olması için Adana'da askeri okula vermiştir. Kadının oğlu askeri okulda şehit olmuştur. Bunun üzerine kadın duygularını ağıtlaştırarak günümüze kadar ulaştırmıştır. Küçük yaşlardan itibaren vatana verilen son evlada yakılan ağıt milli hassasiyetin en büyük göstergesidir.

Ülkemizin zor dönemlerinde asker olup cephede mücadele eden Pınarbaşı insanın vatan müdafaası noktasında ödediği bedelleri ağıt metinlerinden çıkarmak mümkündür. 1938 yılında meydana gelen Dersim ayaklanmasında şehit olan Karamanlı köyünden Mehmet'e yazılan ağıt dönemin ruhunu yansıtması açısından oldukça önemlidir.

Gül dağında şehit düşmüş

Boz uruba donuyunan

Hakkı sırtında getirmiş

Ilgit 1lgit kanıyınan (Altınkaynak, 2015: 253)

Toplumların içinde bulunduğu zor durumdan kurtulmasının yolu milli birlik ve beraberliktir. Bundan dolayı toplum çeşitli makamlara özel anlamlar ve ona kutsallıklar yüklemektedir. Şehitlik bu makamların en başında gelendir. Vatan ve millet için canını verenlere yazılan ağıtlarda milli bilincin genişlemesinde hayat suyu fonksiyonu görmektedir.

\section{Sonuç}

Sözlü kültür ürünleri kültürel belleği aktarmada önemli bir araçtır. Merkezinde insani özü barındıran sözlü kültür ürünleri doğumdan ölüme insan yaşamının birer aynası gibidir. Ölüm karşısında yakılan ağıtlar da kültürel bellek ürünlerini bünyesinde barındırır. Acı bir olay neticesinde ortaya çıkmasına karşın ağıtlarda kültürün pek çok unsuru yer almaktadır.

Pınarbaşı ve yöresi zengin bir kültürel birikime sahiptir. Bu birikimi ağıtların içeriği incelendiğinde görmek mümkündür. Pınarbaşı ağıtlarında tarihi kişilikler, giyim kuşam kültürü, yemek kültürü, halk inanışları ve geçiş dönemlerine ait bilgiler yer almaktadır. Ağıtların sözlü kültür aracılığıyla tekrarlanıyor oluşu kültürel belleği canlı tutmakta ve kültürel birikim gelecek kuşaklara aktarılmaktadır.

Pınarbaşı ağıtlarında dikkati çeken bir başka unsur ise bu ağıtların milli kimlik yaratmadaki önemidir. Milli kimlik yaratmada ağıtların en büyük yardımcısı ise tarihi olaylar ve tarihi kişiliklerdir. Genel olarak ülkemizin kahramanlık destanı 
olan savaşların, ağıtlarda işlendiğine ve şehitlik gibi kutsal bir olgunun kimlik inşasında önemli bir yer edindiği görülür.

Sonuç olarak Pınarbaşı ağıtları kültürel bellek ve millik kimlik yaratmada genelde Türk kültürünün binlerce yıllık birikiminden özelde ise Pınarbaşı ve yöresinin sahip olduğu kültürel zenginlikten yararlanır. Böylece bu ağıtlar gelecek nesillere ulaşarak geçmiş ve gelecek arasında kurulacak olan bağın en önemli araçlarından biri haline dönüşürler.

\section{Kaynakça}

Altınkaynak, E. (2015). Ağıtlar (Pınarbaşı, Sarız, Tomarza Avşarları), Karadeniz Dergi Yay., Ankara.

Assmann, J. (2015), Kültürel Bellek (Çev. Ayşe Tekin), Ayrıntı Yay., İstanbul.

Baltaş, Z. (2000). Sağlık Psikolojisi. Remzi Kitabevi, İstanbul.

Güvenç, B. (1997), Türk Kimliği, Remzi Kitapevi, İstanbul.

Çağırkan, B. (2016). Göç, Hibrit Kimlik ve Aidiyet: Yeni Toplumlar, Yeni Kimlikler. İnsan ve Toplum Bilimleri Araştırmaları Dergisi, 5(8), 2613-2623.

Elçin, Ş. (2004). Halk Edebiyatına Giriş, Akçağ Yay., Ankara.

Kaya, D. (2007). Ansiklopedik Türk Halk Edebiyatı Terimleri Sözlüğü, Akçă̆ Yay., Ankara.

Korkmaz, R. (2008). Aytmatov Anlatılarında Ötekileşme Sorunu ve Dönüş İzlekleri, Grafiker Yay., Ankara.

Morley, D. ve Robıns, K. (1997). Kimlik Mekânları (Küresel Medya, Elektronik Ortamlar ve Kültürel Sinırlar), (Çev. Emrehan Zeybekoğlu), Ayrıntı Yayınları, İstanbul.

Smith, Anthony D. (1994). Milli Kimlik, (Çev: Bahadır Sina Şener), İletişim Yayınlar1, İstanbul.

Şimşek, E. (1993). Kadirli ve Osmaniye Ağıtları, Antakya, 1993

URL- 1: www.tdk.gov.tr, erişim tarihi: 02.07.2020, erişim saati: 14:20. 